\title{
NOTE
}

\section{Liver lesions in cultured Oreochromis hybrids caused by amoeboid organisms similar to the aetiological agent of goldfish kidney granuloma}

\author{
I. Paperna ${ }^{1}$, S.-H. Kim ${ }^{1}$, E. Hammerschlag ${ }^{2}$ \\ ${ }^{1}$ Department of Animal Sciences, Faculty of Agriculture of the Hebrew University of Jerusalem, Rehovot 76-100, Israel \\ ${ }^{2}$ Migal, Galilee Technological Center, Kiriat Shmona 10200, Israel
}

\begin{abstract}
Autopsies of cultured hybrid cichlids (Oreochromis aurea $\times$ nilotica) from dying-off overwintering stock revealed focal white lesions in the liver, which, upon histological examination, were found to be filled with masses of amoeboid organisms. These were reminiscent of the causative agents of goldfish kidney granuloma. The lesions were granulomata comprised of degenerating epitheloid cells surrounding a gradually expanding necrotic core. The amoeboid organisms occurred both inside and outside the host cells, and in the granuloma's cellular and necrotic components; a few were also found in the surrounding liver cells.
\end{abstract}

KEY WORDS: Oreochromis hybrids - Liver lesions - Granuloma-Amoeboid organisms Israel

Autopsies performed in February 1992 on cultured cichlid (tilapia) hybrids of Oreochromis aurea and $O$. nilotica from a gradually dying-off overwintering stock revealed variable numbers of white focal lesions in the liver. Other organs did not contain such lesions. Every winter, the farm, located in the northern Jordan Valley of Israel, holds Oreochromis hybrids stocked at a biomass of 10 to $12 \mathrm{~kg} \mathrm{~m}^{-3}$ in three $800 \mathrm{~m}^{3}$ cement-lined ponds protected by a plastic green-house. Water temperature is maintained at 15 to $17^{\circ} \mathrm{C}$, with an ambient air temperature of 8 to $13^{\circ} \mathrm{C}$. The fish suffered from systemic streptococcosis in winter 1991 to 1992 . Overwintering stocks in these ponds also suffered mortalities during February and early March of 1993 and 1995. In 1993, cases of pasteurellosis (Pasteurella multocida) were diagnosed (Nizan \& Hammerschlag 1993), whereas in 1995, observed anemia and nephrocalcinosis suggested stress-related metabolic aberrations. Overwintering fish were also persistently infected with a gut Hexamita. The pH, oxygen, ammonia and nitrite levels monitored in the ponds were usually maintained within the optimal range.
Materials and methods. Livers, as well as other visceral organs, were fixed in buffered neutral formalin $(10 \%)$ and embedded in glycol-methacrylate (GMA, Agar Scientific Ltd, Stansted, UK). Sections 3 to $4 \mu \mathrm{m}$ thick were cut on a Sorval JB4 glass knife microtome and stained in Meyer's haemalum-eosin.

Results and discussion. Histology of the liver revealed numerous focal granulomata comprised of a superficial layer of fibroblasts and epitheloid cells enclosing an inner zone of mostly swollen degenerated cells (Fig. 1). Some of the granulomata also contained a necrotic matrix core, whereas some lesions consisted entirely of necrotic material and cell debris. Both the inner degenerated cells and those in the lesion's peripheral zone were perfused with numerous amoeboid cells 2 to $3 \mu \mathrm{m}$ (Figs. 2 to 4 ) in diameter. These cells contained a single dense body, presumably the nucleus. Only exceptionally did parasitic cells contain more than 1 dense granule. Amoeboid cells also densely filled lesions which were completely necrotic (Fig 5). A few amoeboids were also traced in the surrounding hepatic tissue.

The early histopathological changes resembled those occurring with granulomata induced by mycobacteria, and at a later stage the necrotic lesions caused in pasteurellosis (Fig. 3 i Paperna in press). However the presence of numerous amoeboid organisms, particularly in association with the lesions, strongly suggests their being the causative agent. The organisms occurred within, as well as among, the cells. The halo often traced around a single or bunch of ameboid cells, as well as their abundance in swollen degenerated cells, may be evidence of their harmful effect on the host cell (Fig. 2). Their concentration in necrotic tissues could also suggest a scavenging action, typical of both free and parasitic amoebae. Amoebic organisms have 


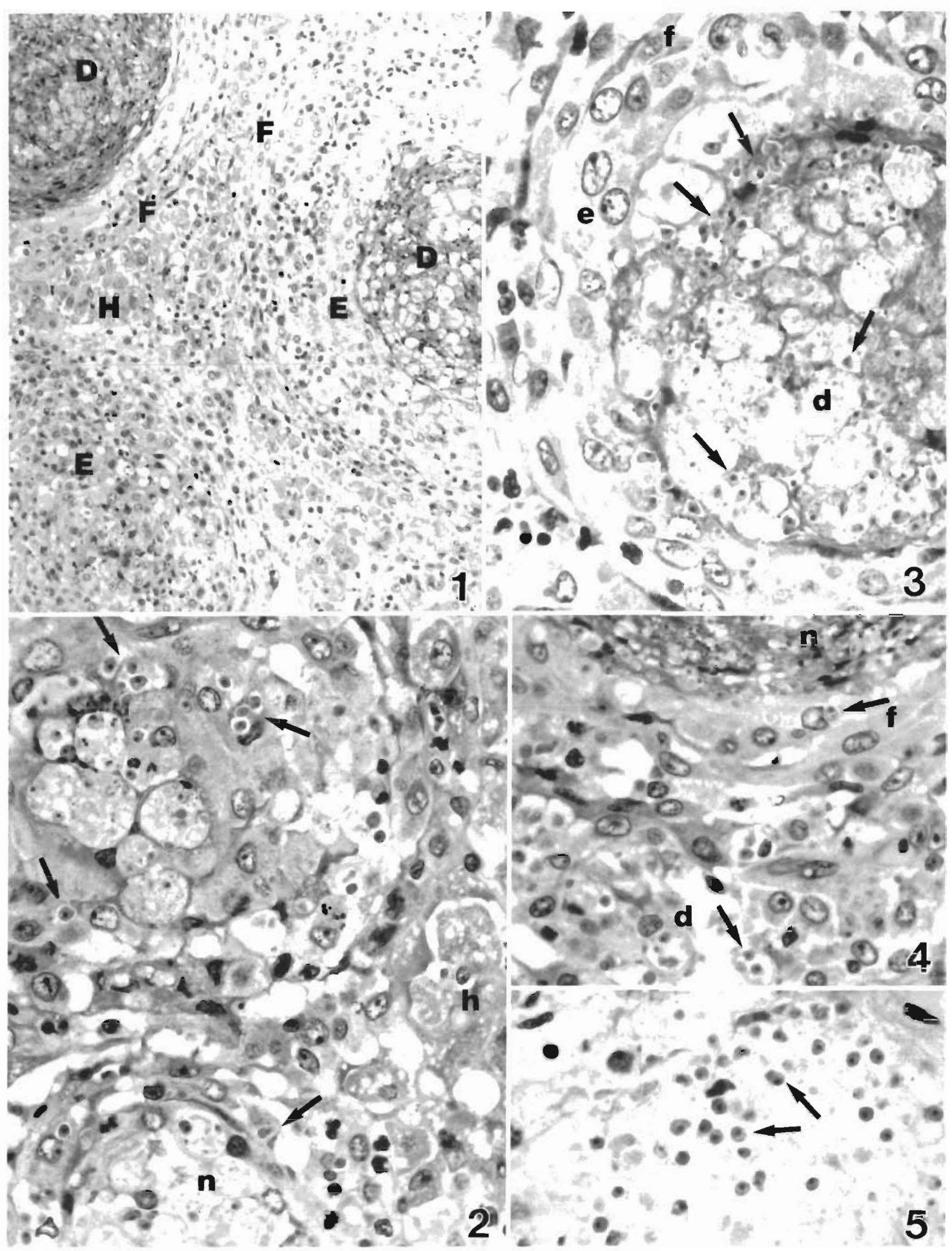


Figs. 1 to 5. Oreochromis aurea. Fig. 1 Low magnification view of a histological section from cichlid hybrid liver tissue (H) with granulomatous lesions comprised of an epitheloid (E) layer with a core of degenerated cells (D); inflammatory cells with fibroblasts $(F)$ aggregated at the surface of the granuloma $(\times 400)$. Figs. 2 to 4 . Enlarged views of the granulomata revealing the amoeboid organisms (arrows), among and inside swollen degenerated cells (d), within a necrotic motrix (n), among remaining intact hepatocytes (h), peripheral epithelord cells (e) and fibroblasts (f) $(\times 1200)$. Fig. 5. Amoeboid cells (arrows) within an enclave of a necrotic matrix $(\times 1200)$

been incriminated in a mortality outbreak of Oreochromis aurea stock held in Auburn, Alabama, USA (W Rogers, Department of Fisheries and Allied Aquacultures, Auburn University, Alabama, pers. comm.). The organisms observed here closely resembled the Dermocystidium-like aetiological agents of goldfish systemic granuloma (Landsberg \& Paperna 1992), granulomatosis in carp (Kovacs-Gayer et al. 1986), and systemic infections in salmonids (Hedrick et al. 1989). They were comprised entirely of uninucleate stages, and were smaller than undivided or post-divided uninucleate-stage organisms found in goldfish and carp, but approximately the same size as those from salmonids.

In the cichlid fishes, lesions have been found to be limited to the liver, whereas in goldfish, carp and salmon, kidneys and spleen are mainly affected. In goldfish the aetiological agents have been found only in the kidney lesions (Landsberg \& Paperna 1992). Epizootiological links between infections in goldfish and cichlids are vague: there are no goldfish farms in the region where the outbreak in cichlids occurred, while amoeboid granuloma was never diagnosed in the many examined farmed and feral cichlids obtained from farms also engaged in goldfish breeding. Voelker et al. (1977) have suggested that the goldfish systemic granuloma agents are amoebae belonging to Hartmanellidae. Lom \& Dykova (1992) succeeded in isolating amoebic organisms from affected goldfish, but failed to culture them on agar plates. Fine structural data from goldfish (Voelker et al. 1977, Kovacs-Gayer et al. 1986, Lom \& Dykova 1992, Steinhagen et al. 1993, Paperna \& Kim 1996) and salmonids (McVicar \& Wooten 1980, Hedrick et

Responsible Subject Editor: W. Körting, Hannover, Germany al. 1989), however, do not provide, in our opinion, conclusive evidence of the affiliation of these organisms with Amoebae.

Acknowledgement. This work was supported by the National Council for Research and Development of the Ministry of Sciences and Arts, Israel, grant no. 2763.

\section{LITERATURE CITED}

Hedrick RP, Fridman CS, Modin J (1989) Systemic infection in Atlantic salmon Salmo salar with a Dermocystidium-like species. Dis Aquat Org 7:171-177

Kovacs-Gayer E, Csaba G, Ratz F, Bekesi L, Szakolczai J (1986) Granulomatosis of common carp (Cyprinus carpio L.). Bull Eur Ass Fish Pathol 6:72-75

Landsberg JH, Paperna I (1992) Systemic granuloma in goldfish caused by a Dermocystidium-like aetiological agent. Dis Aquat Org 13:75-78

Lom J, Dykova l (1992) Protozoan parasites of fishes. Elsevier, Amsterdam

McVicar AH, Wooten R (1980) Disease in farmed juvenile Atlantic salmon caused by Dermocystidium sp. In: Ahne W (ed) Fish diseases. Third Cooperative Programme of Research on Aquaculture Session. Springer-Verlag, Berlin, p 165-173

Nizan S, Hammerschlag E (1993) First report of pasteurellosis in freshwater hybrid tilapia (Oreochromis aureus $\times 0$. niloticus) in Israel. Bull Eur Ass Fish Pathol 13:179-180

Paperna l (in press) Parasites, infections and diseases of fish in A.frica, an update. FAO Fish Tech Pap

Paperna I, Kim SH (1996) Ultrastructure of the aetiological agent of systemic granuloma in goldfish. Dis Aquat Org (in press)

Steinhagen D, Jendrysek S, Korting W (1993) Fallbericht: Amobiasis bei Goldfischen. Kleintierpraxis 38:469-474

Voelker FA, Anver MR, McKee AE, Cassey HW, Brenniman GR (1977) Amebiasis in goldfish. Vet Pathol 14:247-255

Manuscript first received: July 17, 1995

Revised version accepted: November 30, 1995 